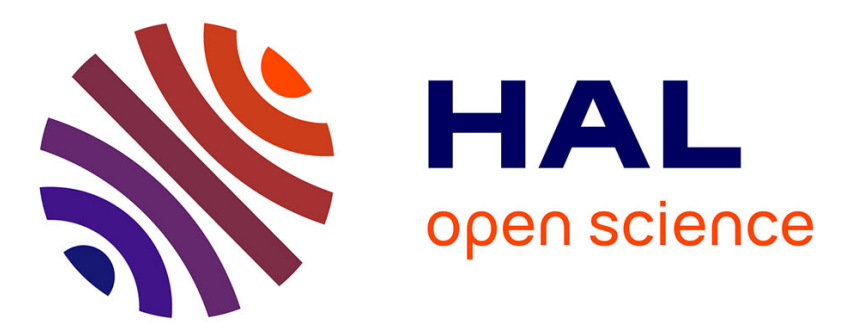

\title{
Significance of variation in extent of recrystallization of zircon in orogenic eclogite
}

Donna L. Whitney, Clementine Hamelin, Christian Teyssier, Francoise Roger, Rey Patrice

\section{- To cite this version:}

Donna L. Whitney, Clementine Hamelin, Christian Teyssier, Francoise Roger, Rey Patrice. Significance of variation in extent of recrystallization of zircon in orogenic eclogite. 22nd EGU General Assembly 2020, May 2020, Vienne, Austria. 10.5194/egusphere-egu2020-10658 . hal-02983339

\section{HAL Id: hal-02983339 \\ https://hal.science/hal-02983339}

Submitted on 11 Dec 2020

HAL is a multi-disciplinary open access archive for the deposit and dissemination of scientific research documents, whether they are published or not. The documents may come from teaching and research institutions in France or abroad, or from public or private research centers.
L'archive ouverte pluridisciplinaire HAL, est destinée au dépôt et à la diffusion de documents scientifiques de niveau recherche, publiés ou non, émanant des établissements d'enseignement et de recherche français ou étrangers, des laboratoires publics ou privés. 
EGU2020-10658

https://doi.org/10.5194/egusphere-egu2020-10658

EGU General Assembly 2020

(c) Author(s) 2020. This work is distributed under

the Creative Commons Attribution 4.0 License.

\title{
Significance of variation in extent of recrystallization of zircon in orogenic eclogite
}

\author{
Donna Whitney ${ }^{1}$, Clementine Hamelin ${ }^{1}$, Christian Teyssier ${ }^{1}$, Francoise Roger ${ }^{2}$, and Patrice Rey ${ }^{3}$ \\ ${ }^{1}$ University of Minnesota, Earth Sciences, Minneapolis, United States of America (dwhitney@umn.edu) \\ ${ }^{2}$ Laboratoire Géosciences, Université Montpellier, France \\ ${ }^{3}$ School of Geosciences, University of Sydney, Sydney, Australia
}

Migmatite domes are common structures in orogens, and in some cases are comprised of deeplysourced crust that experienced lateral and subsequent vertical flow, with ultimate emplacement in the mid/upper crust. The record of the deep-crustal history survives in layers and lenses of refractory rock types within the dominant quartzofeldspathic gneiss. These deep-crustal relics are typically the best archives of pressure-temperature-time-deformation conditions of crustal flow, although it can be difficult to extract information about the duration of deep-crustal residence such as might accompany lateral flow of deep-crust - because intracrystalline diffusion at protracted high temperatures may erase much of the history and/or minerals may record only the timing of final emplacement and cooling. One possible indicator of deep-crustal history is the extent of recrystallization of zircon that experienced eclogite-facies conditions; the conditions of zircon growth/recrystallization are indicated by REE abundance and results of Ti-in-zircon thermometry. For example, in the eclogite-bearing Montagne Noire migmatite dome of the southern French Massif Central, zircon in eclogite from the core of the dome has been extensively recrystallized under eclogite-facies conditions. In contrast, zircon in eclogite from the margin of the dome experienced very little recrystallization and largely consists of inherited (magmatic) cores with very thin $(<20 \mathrm{um})$ eclogite-facies rims. The two eclogites, which both contain garnet + omphacite + rutile + quartz, record the same age of protolith crystallization ( 450 Ma) and high-P metamorphism ( $\sim 315 \mathrm{Ma})$, and similar metamorphic conditions $\left(700 \pm 20^{\circ} \mathrm{C}, 1.4 \pm 0.1 \mathrm{GPa}\right)$. Differences in extent of recrystallization of zircon in the two eclogites may relate to duration at high $\mathrm{T}$ and/or extent of interaction with aqueous fluid (ongoing work to obtain in situ oxygen isotope data for zircon and garnet will evaluate the latter for each eclogite). Deformation may have been involved in recrystallization of zircon, but is not the primary factor accounting for the differences in extent of recrystallization; both eclogites were deformed during eclogite-facies metamorphism, as indicated by crystallographic-preferred orientation of omphacite and shapepreferred orientation of rutile. Other variables that are also unlikely to explain differences in these eclogite zircons are differences in host rock chemistry, availability of Zr from decompression reactions involving $\mathrm{Zr}$-bearing minerals, extent of radiation damage, and original crystal size. The two most likely explanations for variations in zircon recrystallization are duration at high-T and extent of fluid-rock interaction. In the case of the former, dome-margin eclogite may have had a shorter residence time in the deep crust and was more directly exhumed from a proximal source, 
whereas the dome-core eclogite may have had a more extended transit in the deep-crust before being exhumed in the steep, median high-strain zone of the migmatite dome. 